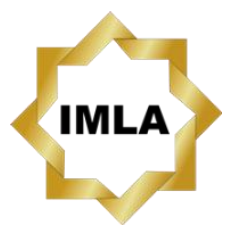

Available online:

http://journal.imla.or.id/index.php/arabi

Arabi : Journal of Arabic Studies, 4 (1), 2019, 87-99

DOI: http://dx.doi.org/10.24865/ajas.v4i1.117

\title{
KEBUTUHAN PESERTA DIDIK DAN RANCANG BANGUN MEDIA PEMBELAJARAN BAHASA ARAB DI MADRASAH ALIYAH

\author{
Erfan Gazali, Hasan Saefuloh
} \\ Institut Agama Islam Negeri Syekh Nurjati Cirebon, Indonesia \\ E-mail : erfangazali@syekhnurjati.ac.id
}

\begin{abstract}
This study aimed to map the Arabic learning needs of Islamic senior high school students (Madrasah Aliyah) in the Cirebon city and Cirebon regencies. This research is the first and second stage of the four stages of the 'Four Door' (4D) research model. The 4D research model has four stages: (1) Defining, (2) Design, (3) Developing, and (3) Disseminating. The "Define" stage includes analysis of student needs. Questionnaire was used as an instrument in analyzing these needs. The needs analysis questionnaire was distributed to students to identify their needs and targets for learning Arabic. Respondents consisted of Madrasah Aliyah students in the 2018-2019 academic year totaling 612 students. Data from the needs analysis questionnaire were analyzed using frequency distributions and percentages and the results were then used as a basis for designing and developing e-learning learning models that matched their learning needs and targets. In the 'design' stage, the flipped classroom learning model was used and elaborated with learning theories, namely the constructive learning environment theory (Constructivist Learning Environment-CLES), Learning Management System (LMS), and Flipped classroom.
\end{abstract}

Keywords: Arabic learning, 4D models, needs analysis, Islamic senior high school

\begin{abstract}
Abstrak
Penelitian ini bertujuan untuk memetakan kebutuhan belajar bahasa Arab siswa Madrasah Aliyah di Kota dan Kabupaten Cirebon. Penelitian ini merupakan tahap pertama dan kedua dari empat tahapan model penelitian 'Four Door' (4D). Model ini memiliki empat tahap, yaitu: (1) Mendefinisikan, (2) Mendesain, (3) Mengembangkan, dan (3) Menyebarluaskan. Pada tahap "Pendefinisian" mencakup analisa kebutuhan siswa. Kuesioner sebagai instrumen dalam menganalisis kebutuhan tersebut. Kuesioner analisis kebutuhan didistribusikan kepada siswa untuk mengidentifikasi kebutuhan dan target mereka dalam belajar bahasa Arab. Responden terdiri dari siswa Madrasah Aliyah tahun akademik 2018-2019 yang berjumlah 612 siswa. Data dari kuesioner analisis kebutuhan dianalisis menggunakan distribusi frekuensi dan persentase. Kemudian hasilnya digunakan sebagai dasar untuk merancang dan mengembangkan model pembelajaran e-learning yang menyesuaikan kebutuhan dan target pembelajaran mereka. Pada tahap perancangan mengunakan model pembelajaran flipped classroom dengan mengelaborasi beberapa teori pembelajaran, yaitu teori lingkungan pembelajaran konstruktivistik (Constructivist Learning Environment-CLEs), Learning Management System (LMS), dan Flipped classroom.
\end{abstract}

Kata Kunci: pembelajaran bahasa Arab, model 4D, analisis kebutuhan, madrasah aliyah 


\section{Arabi : Journal of Arabic Studies}

\section{Pendahuluan}

Tujuan utama penelitian ini adalah memetakan kebutuhan belajar bahasa Arab siswa Madrasah Aliyah di Kota dan Kabupaten Cirebon dan merancang model pembelajaran sesuai dengan kebutuhan dan target pembelajaran mereka. Penelitian ini merupakan tahap pertama dan kedua dari empat rangkaian tahapan model penelitian 'Four Door' (4D) yang dikembangkan oleh Thiagarajan, Semmel, \& Semmel (1974).

Analisis kebutuhan, sebagai istilah yang berhubungan dengan pengajaran bahasa, pertama kali muncul pada tahun 1920 (White, 1988,West, 1997). Namun, menjadi populer pada dekade 70an dan awal 80-an dengan munculnya beberapa karya terkait analisis kebutuhan dengan pengajaran English for specific purposes (ESP) seperti karya Richterich \& Chancerel (1980) atau (Munby 1978). Istilah need analysis juga disebut dengan istilah need assessment (Richards, 2001; Hayland, 2006; Hutchinson \& Waters, 1987; Graves, 2000). Istilah Needs menurut Hayland (2006:73) adalah istilah payung yang membawahi beberapa aspek seperti menggali informasi tentang tujuan belajar dan motivasi belajar siswa, kemampuan berbahasa siswa, preferensi kegiatan belajar siswa dan target situasi di mana mereka akan berkomunikasi dengan bahasa tersebut. Menganalisis kebutuhan peserta didik merupakan langkah awal untuk mendesain sebuah pembelajaran, dan secara spesifik berfungsi sebagai acuan untuk menentukan 'apa' dan 'bagaimana' dari sebuah pembelajaran bahasa. Chen (dalam Jiajing, 2007) juga mencapai kesimpulan bahwa tahapan awal yang harus dilakukan desainer atau pengajar bahasa adalah mengeksplorasi dan mengidentifikasi kebutuhan dan potensi peserta didik.

Dalam sudut pandang pembelajaran bahasa, upaya analisis kebutuhan menurut Richterich \& Chancerel (1980) harus mencakup informasi peserta didik yang akan mengikuti pembelajaran bahasa dan harapan atau keinginan mereka memanfatkan bahasa setelah menyelesaikan pembelajaran. Menurut Brindley (1989) kata needs (kebutuhan) berbanding sama dengan want (keinginan) atau desires (harapan) yang mengacu pada apa yang peserta didik inginkan dalam belajar. Hal yang serupa juga dikemukan oleh Berwick (1989) yang mendefinisikan kebutuhan sebagai kesenjangan antara situasi saat ini dengan kebutuhan masa depan. Dari ketiga pendapat tersebut disimpulkan bahwa analisis kebutuhan merupakan upaya yang berorientasi pada proses dan lebih berfokus pada apa yang peserta didik perlukan selama belajar bahasa atau keuntungan apa yang akan mereka ingin peroleh dari proses kegiatan pembelajaran bahasa. Untuk meringkas, kebutuhan berorientasi pada tujuan berasal dari situasi target dan kebutuhan proses-berorientasi berasal dari situasi belajar.

Perspektif pembelajaran bahasa era modern telah menjadikan peran peserta didik dan pendidik memiliki peran keaktifan dan kreatifitas yang sama dalam sebuah pembelajaran. Keputusan penting tentang semua aspek pengajaran bahasa dibuat dengan mengacu pada variabel yang berasal dari peserta didik. Guru tidak lagi menjadi "pengarah gerak dalam permainan panggung", tetapi mereka adalah fasilitator, konselor, dan analis kebutuhan. Mereka harus menganalisis perubahan kebutuhan peserta dan mengatur pembelajaran bahasa dengan sedemikian rupa sehingga memenuhi kebutuhan pembelajar bahasa. Dalam perspektif ini, peserta didik dianggap mampu bertanggung jawab atas pembelajaran mereka sendiri dan harus mampu mengembangkan kemandirian, otonomi (kebebasan mengambil keputusan) tetapi juga memiliki tanggung jawab. Jadi, mereka harus dilatih untuk mengidentifikasi strategi belajar mereka sendiri dan mencoba strategi baru untuk meningkatkan pembelajaran mereka sendiri tanpa bergantung pada guru mereka sendiri (Sadeghi, Hassani, dan Hessari 2014).

Belajar bahasa hakikatnya adalah belajar komunikasi. Pembelajaran bahasa Arab di Madrasah Aliyah berdasarkan KMA no 165 tahun 2014, tentang kurikulum 2013 mata pelajaran Pendidikan Agama Islam dan Bahasa Arab di Madrasah, memiliki tujuan sebagai berikut:1) Mengembangkan kemampuan berkomunikasi dalam bahasa Arab, baik lisan maupun tulis yang mencakup empat kecakapan berbahasa, yakni menyimak (istimā'), berbicara (kalām), membaca (qirāah), dan menulis (kitābah). 2) Menumbuhkan kesadaran tentang pentingnya bahasa Arab 
sebagai salah satu bahasa asing untuk menjadi alat utama belajar, khususnya dalam mengkaji sumber-sumber ajaran Islam. 3) Mengembangkan pemahaman tentang saling keterkaitan antara bahasa dan budaya serta memperluas cakrawala budaya. Dengan demikian, peserta didik diharapkan memiliki wawasan lintas budaya dan melibatkan diri dalam keragaman budaya".

Berdasarkan regulasi yang berkaitan dengan target penguasaan bahasa Arab yang harus dicapai oleh siswa madrasah Aliyah, pertanyaan mendasarnya adalah: bagaimana kemampuan bahasa Arab siswa dan alumni ditingkat Madrasah Aliyah yang ada di Indoensia secara umum? Apakah target yang dicapai memenuhi standar yang ditetapkan? Apakah proses pembelajaran di kelas telah dibangun sesuai kebutuhan siswa?

Untuk menjawab pertanyaan tersebut, terutama gambaran pembelajaran bahasa Arab tingkat madrasah khususnya madrasah aliyah tergambarkan dari hasil penelitian yang telah dilaksanakan diantaranya, Saefuloh (2015) yang menyebutkan bahwa pembelajaran bahasa di tingkat madrasah telah mengalami kegagalan, dalam tulisannya ia meyebutkan beberapa faktor yang menyebabkan kondisi tersebut. Satu diantaranya adalah para guru 'terkondisikan' dalam pengajaran bahasa Arab khususnya di tingkat Aliyah, para guru hanya berorientasi pada tuntasnya materi ajar dengan tidak memprioritaskan capaian kompentensi bahasa siswa, hal ini dikarenakan capaian kompetensi yang dititipkan dalam setiap tema tidak sebanding dengan durasi tatap muka yang ada di madrasahmadrasah sehingga menyebabkan capaian nilai ketuntasan siswa terhadap pelajaran bahasa Arab di Madrasah Aliyah Negeri khususnya wilayah Cirebon rata-rata adalah 70 masih dibawah standar ketuntasan Minimum yaitu 80.

Senada dengan Saefuloh (2015), kajian Hizbullah dan Mardiah (2014) terkait masalah pengajaran bahasa Arab di Madrasah Aliyah wilayah Jakarta menunjukkan mayoritas guru terkendala dengan jumlah jam pelajaran bahasa Arab yang menjadi pangkal segala permasalahan bagi sebagian besar guru. Mereka mengaku sulit bergerak di waktu yang tak lebih dari 2 s.d 4 jam sepekan. Mengingat banyaknya jumlah pelajaran lain dan padatnya jadwal serta jam belajar di sekolah, para guru harus memutar otak bila harus mengagendakan kegiatan tambahan di luar kelas. Itu pun harus seizin dan sepersetujuan pimpinan madrasah. Hal tersebut membuat para guru tidak terlalu tertarik dan termotivasi untuk menjadwalkan kegiatan pengayaan pelajaran bahasa Arab. Selain itu, guru juga memahami tidak mungkin membebani siswa dengan hal-hal terkait pelajaran di luar jam belajar, baik di sekolah apalagi di luar sekolah. Kalaupun ada pekerjaan rumah yang diberikan, itu pun masih sebatas latihan terstruktur maupun latihan mandiri yang erat kaitannya dengan materi pelajaran. Tidak mudah memberikan tugas pengembangan kemampuan siswa di luar alokasi waktu yang ada di sekolah.

Selain itu, temuan lain yang didapatkan oleh Hizbullah dan Mardiah (2014) bahwa input siswa MA yang bervariasi menjadi kendala sendiri bagi guru bahasa Arab dalam proses pengajaran di kelas. Siswa MA dari lulusan Madrasah Tsanawiyah (MTs) dan/atau pondok pesantren relatif lebih dapat dengan mudah memahami tujuan pembelajaran bahasa Arab yang disampaikan oleh para guru. Adapun siswa dari kelompok lain yang berlatar pendidikan sekolah menengah pertama umum (SMP) yang baru pertama kali belajar bahasa Arab membutuhkan waktu untuk dapat memiliki orientasi belajar yang sesuai dengan tujuan pembelajaran bahasa Arab itu sendiri. Siswa pada kelompok ini masih harus dipahamkan oleh guru tentang kedudukan dan fungsi pelajaran bahasa Arab dalam struktur kurikulum maupun keilmuan Islam. Perbedaan orientasi belajar ini penting untuk segera diatasi oleh para guru agar nantinya pada tahapan pengajaran hal itu tidak menjadi kendala bagi siswa untuk mencapai kemampuan belajar yang diharapkan. Upaya penyamaan orientasi dan standar kompetensi minimum bagi siswa MA berdampak pada kuantitas tatap muka di ruang kelas dan proses pembelajaran itu sendiri.

Kondisi tersebut pada akhirnya membutuhkan upaya yang efektif dalam mendorong peningkatan kualitas hasil belajar siswa madrasah, khususnya pembelajaran bahasa Arab di Madrasah Aliyah sehingga target capaian yang ditetapkan oleh pemangku kebijakan dapat 


\section{Arabi : Journal of Arabic Studies}

terpenuhi tanpa harus dimanipulasi, langkah utama yang perlu dilakukan adalah memberikan alternatif model pembelajaran bahasa arab yang dirancang berdasarkan kebutuhan siswa.

\section{Metode Penelitian}

Penelitan ini merupakan tahapan pertama dan kedua dari empat tahapan penelitian dan pengembangan pendidikan (Educational Research and Development) yang sedang peneliti lakukan. Model penelitian menganut model 4D atau Four-Door (4D) model (Thiagarajan, Semmel, dan Semmel 1974). Model 4D memiliki empat tahapan yaitu tahap pendefinisian (define), tahap perencanaan (design), tahap pengembangan (develop) dan tahap penyebaran (disseminate). Dalam kajian ini peneliti hanya menyajikan sebagian data dari dua tahapan pertama, yaitu: tahap pendefinisian (define) dan tahap perencanaan (design).

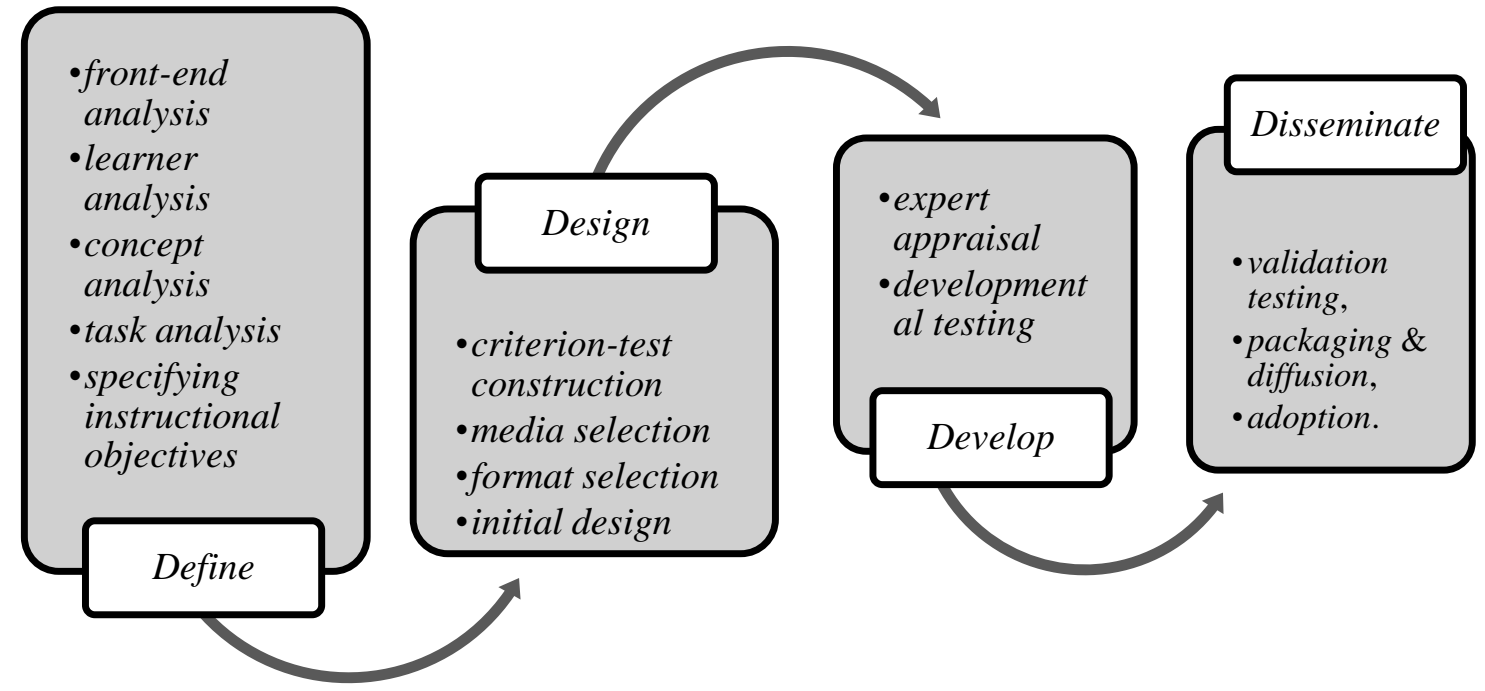

Gambar 1 Alur Pengembangan model 4D

(Thiagarajan, Semmel, dan Semmel 1974)

Pada tahapan pendefinisian (define) mencakup lima langkah pokok, yaitu (1) analisis ujung depan (front-end analysis); (2) analisis peserta didik (learner analysis); (3) analisis konsep (concept analysis); (4) analisis tugas (task analysis); dan (5) perumusan tujuan pembelajaran (specifying instructional objectives). Selanjutnya tahapan kedua yaitu perancangan (disign).

Tahap perancangan bertujuan untuk merancang perangkat pembelajaran. Empat langkah yang harus dilakukan pada tahap ini, yaitu: (1) penyusunan standar tes (criterion-test construction), (2) pemilihan media (media selection) yang sesuai dengan karakteristik materi dan tujuan pembelajaran, (3) pemilihan format (format selection), yakni mengkaji format- format bahan ajar yang ada dan menetapkan format bahan ajar yang akan dikembangkan, dan (4) membuat rancangan awal (initial design) sesuai format yang dipilih.

Subjek pada penelitian ini adalah siswa madrasah aliyah negeri (MAN) dan madrasah aliyah swasta (MAS) di Kota dan Kabupaten Cirebon dengan jumlah sampel sebanyak 612 siswa Madrasah Aliyah kelas X, XI dan XII tahun ajaran 2018-2019. Teknik pengumpulan data pada penelitian ini menggunakan teknik purposive sampling.

Sugiyono (2013: 61) menyatakan bahwa purposive sampling adalah teknik penent uan sampel dengan pertimbangan tertentu, di mana didasarkan atas kriteria-kriteria tertentu, yaitu mempertimbangkan waktu dan kesediaan dari responden yang diterapkan berdasarkan tujuan penelitian. Pengumpulan data menggunakan kuesioner (angket). Ada dua Jenis angket yang digunakan, angket daring dan angket kertas. Data angket ditabulasi dan dianalisis dengan mengunakan distribusi frekuensi dan persentase. 


\section{Hasil Penelitian dan Pembahasan Hasil survei kebutuhan siswa}

1. Latar belakang siswa (Demographic Background)

Tabel 1. Latar belakang dan karakteristik siswa MA

\begin{tabular}{lllcc}
\hline Latar belakang siswa & & $\begin{array}{c}\text { Frequency } \\
(\mathbf{N})\end{array}$ & Percentage(\%) \\
\cline { 3 - 5 } & \multirow{2}{*}{ Jenis Kelamin } & Laki-laki & 172 & 28,1 \\
& & Perempuan & 440 & 71.9 \\
\hline 2 & Kelas & X & 275 & 44.9 \\
& & XI & 236 & 38,6 \\
& & XII & 101 & 16.5 \\
\hline 3 & Jurusan & IPA & 278 & 45.4 \\
& & IPS & 331 & 54.1 \\
& & Agama & 0 & 0 \\
& & Bahasa & 0 & 0 \\
\hline 4 & Sekolah & MAN & 425 & 69 \\
& & MAS & 147 & 31 \\
\hline 5 & Bahasa Asing yang & Inggris & 509 & 83.2 \\
& pernah dipelajari selain & Mandarin & 25 & 4.1 \\
& bahasa Arab & Jepang & 50 & 8.2 \\
& & Prancis & 17 & 2.8 \\
& & Korea & 62 & 10.1 \\
\hline 6 & Lama masa belajar & $<1$ tahun & 145 & 23.7 \\
& bahasa Arab & $1-3$ tahun & 136 & 22.2 \\
& & $>3$ tahun & 331 & 54.1 \\
\hline 7 & Pengalaman Bicara & Ya & 112 & 18.3 \\
& dengan penutur Arab & Tidak & 500 & 81.7 \\
\hline
\end{tabular}

Tabel 1 diatas mengambarkan karakteristik siswa MA yang menjadi sampel dalam penelitian ini. Jumlah sampel sebanyak 612 responden yang terdiri dari 172 laki-laki (28.1\%) dan 440 perempuan (71,9\%). Mereka berasal dari sekolah di kota Cirebon dan kabupaten Cirebon baik negeri maupun swasta. 425 siswa berasal dari Madrasah Aliyah Negeri (MAN) dan siswanya sebanyak 147 siswa berasal dari Madrasah Aliyah Swasta (MAS) dengan sebaran responden sebagai berikut : (1) responden berasal dari MAN yaitu MAN 1 Kota Cirebon dengan 295 siswa (48\%), MAN 2 kota Cirebon 81 siswa (13\%), MAN 3 Cirebon 49 siswa (8\%); dan (2) responden berasala dari MAS yaitu 45 siswa (8\%) berasal dari MA Madinatun Najah, MAK Salafiyah Kota Cirebon, dari MA Islamic Centre sebanyak 20 siswa (3\%), dari MA Darul Masholeh sebanyak 7 orang (1\%) dan dari MA Annur sebanyak 40 orang (8\%). Mereka berasal dari kelas X sebanyak 275 orang atau 44,9\%, kelas XI sebanyak 236 orang atau 38,6\% dan 101 orang berasal kelas XII atau 16,5\%. Mayoritas responden telah menghabiskan waktu selama lebih dari 3 tahun belajar bahasa Arab yaitu 54.1\%, dan $81.7 \%$ dari mereka belum berinteraksi dengan penutur asli bahasa arab.

2. Kebutuhan Belajar Siswa (Student needs)

Pada aspek kebutuhan belajar siswa terdapat 9 kriteria yang dijaring dalam pertanyaan kuesioner: topik yang diminati, setting pembelajaran di kelas, gaya belajar, format belajar, umpan balik, media, tugas, belajar di luar kelas, dan pemanfaatan teknologi.

a. Topik atau tema materi yang diminati dalam pembelajaran bahasa

Tabel 2. Tema atau topik yang diminati dalam pembelajaran

\begin{tabular}{c|c|c}
\hline Tema yang diminati & $\begin{array}{c}\text { Frequency } \\
(\mathbf{N})\end{array}$ & $\begin{array}{c}\text { Percentage } \\
(\%)\end{array}$ \\
\hline
\end{tabular}


Arabi : Journal of Arabic Studies

\begin{tabular}{l|c|c}
\hline Kegiatan dirumah & 72 & 11.8 \\
\hline Aktivitas sekolah & 203 & 33.2 \\
\hline Keagamaan & 187 & 30.6 \\
\hline Sejarah dan kebudayaan & 101 & 16.5 \\
\hline Biorafi tokoh & 49 & 8 \\
\hline
\end{tabular}

Tema atau topik yang diminati dalam belajar bahasa arab berdasarkan tabel 2 adalah: sebanyak 33.2\% responden memilih topik aktivitas sekolah sebagai tema yang menarik untuk dipelajari dilanjutkan dengan topik keagamaan dengan $30.6 \%$ responden. Untuk sejarah dan kebudayaan berada diurutan ketiga sebesar 16.5\% disusul dengan kegiatan di rumah dan biografi tojoh dengan masing-masing persentase sebesar $11.8 \%$ dan $8 \%$.

b. Jenis kegiatan belajar yang di sukai dalam setting pembelajaran di kelas

Tabel 3. Setting Pembelajaran di kelas

\begin{tabular}{l|c|c}
\hline Setting pembelajar di kelas & $\begin{array}{c}\text { Frequency } \\
\text { (N) }\end{array}$ & $\begin{array}{c}\text { Percentage } \\
(\mathbf{\%})\end{array}$ \\
\hline Membaca, melihat gambar, mengamati. & 209 & 34.2 \\
\hline $\begin{array}{l}\text { Mengemukakan suatu fakta atau prinsip, } \\
\text { menghubungkan suatu kejadian mengajukan } \\
\text { pertanyaan, memberi saran, mengemukakan pendapat, }\end{array}$ & 81 & 13.2 \\
wawancara, diskusi & & \\
\hline $\begin{array}{l}\text { Mendengarkan penyajian bahan, mendengarkan } \\
\text { percakapan atau diskusi kelompok, atau } \\
\text { mendengarkan radio. }\end{array}$ & 57 & 9.3 \\
\hline $\begin{array}{l}\text { Menulis cerita, membuat outline atau rangkuman, dan } \\
\text { mengerjakan tes. }\end{array}$ & 32 & 5.2 \\
\hline $\begin{array}{l}\text { Menggambar, membuat grafik, diagram, peta dan } \\
\text { pola. }\end{array}$ & 31 & 5.1 \\
\hline $\begin{array}{l}\text { Melakukan drama peran (Role play), } \\
\text { menyelenggarakan permainan. }\end{array}$ & 59 & 9.6 \\
\hline $\begin{array}{l}\text { Menghapal, mengingat, memecahkan masalah, } \\
\text { menganalisa faktor-faktor, melihat hubungan- } \\
\text { hubungan, dan membuat keputusan. }\end{array}$ & 110 & 18 \\
\hline \begin{tabular}{l} 
Kuis, lomba bahasa \\
\hline
\end{tabular} & 33 & 5.4 \\
\hline
\end{tabular}

Jenis pembelajaran di kelas yang disetting dengan membaca, melihat gambar, dan mengamati lebih disukai oleh siswa dengan 34.2\% disusul dengan menganalisa dan menghafal sebanyak $18 \%$, kemudian diskusi dan presentasi sebanyak $13.2 \%$, melakukan drama peran $(9,6 \%)$, dan mendengar dalam diskusi kelompok atau audio (9.3\%). Setting kuis atau lomba di minati 5.4\% siswa. Untuk setting menulis cerita atau merangkum 5.2\% dan mengambar diminati 5.1\% siswa.

c. Setting belajar yang anda sukai dalam belajar bahasa

Tabel 4. Setting Belajar

\begin{tabular}{l|c|c}
\hline Setting belajar bahasa & $\begin{array}{c}\text { Frequency } \\
(\mathbf{N})\end{array}$ & $\begin{array}{c}\text { Percentage } \\
(\mathbf{\%})\end{array}$ \\
\hline Individu & 153 & 25 \\
\hline Berpasangan & 112 & 19.9 \\
\hline Kelompok & 337 & 55.1 \\
\hline
\end{tabular}

Berdasarkan tabel 4 menunjukkan tentang setting belajar berkelompok lebih disukai siswa sebesar 55.1\% kemudian 25\% mereka lebih suka belajar secara individu dan berpasangan sebanyak 19.9\% siswa. ini menunjukkan bahwa mereka lebih senang belajar dengan sistem kolaborasi.

d. Tugas Belajar untuk pengembangan bahasa Arab

Tabel 5. Tugas Belajar

Tugas Belajar Frequency $\quad$ Percentage 
Arabi : Journal of Arabic Studies

\begin{tabular}{l|c|c}
\hline & $(\mathbf{N})$ & $\mathbf{( \% )}$ \\
\hline Menulis Artikel & 69 & 11.3 \\
\hline Presentasi dan diskusi & 221 & 36.1 \\
\hline Menjawab soal & 270 & 44.1 \\
\hline Membuat film dokumen berbahasa arab & 52 & 8.5 \\
\hline
\end{tabular}

Pada tabel 5 menunjukkan bahwa tugas belajar yang disukai oleh siswa adalah menjawab soal sebanyak $44.1 \%$ atau 270 siswa. Disusul dengan penyiapan presentasi dan diskusi sebanyak $36.1 \%$ atau 221 siswa, menulis artikel dan membuat dokumen dengan masing-masing persentase sebesar $11.3 \%$ dan $8.5 \%$.

e. Gaya belajar bahasa yang disukai ketika di luar kelas

Tabel 6. Gaya Belajar

\begin{tabular}{l|c|c}
\hline Gaya Belajar & $\begin{array}{c}\text { Frequency } \\
(\mathbf{N})\end{array}$ & $\begin{array}{c}\text { Percentage } \\
(\mathbf{\%})\end{array}$ \\
\hline $\begin{array}{l}\text { Menghapal dengan suara keras dan suasana yang } \\
\text { tenang }\end{array}$ & 215 & 35.1 \\
\hline Mengerjakan soal-soal latihan, praktek dan simulasi & 135 & 22.2 \\
\hline $\begin{array}{l}\text { Membuat sketsa, diagram atau dan mencatat ulang } \\
\text { materi }\end{array}$ & 45 & 7.4 \\
\hline Berdiskusi, mengingat kata-kata kunci & 216 & 35.3 \\
\hline
\end{tabular}

Pada tabel 6 menunjukkan bahwa gaya belajar auditori sebanyak 35.1\% atau 215 siswa, gaya kinestetik sebanyak $22.2 \%$ atau 135 siswa, gaya visual sebanyak $7.4 \%$ dan verbal (linguistik) sebanyak $35.3 \%$.

f. Waktu umpan balik (tanggapan bisa saran, arahan, apresiasi dan koreksi) yang disukai ketika praktik membaca arab

Tabel 7. Umpan balik dalam praktik membaca

\begin{tabular}{l|c|c}
\hline Umpan Balik & $\begin{array}{c}\text { Frequency } \\
(\mathbf{N})\end{array}$ & $\begin{array}{c}\text { Percentage } \\
(\mathbf{\%})\end{array}$ \\
\hline $\begin{array}{l}\text { Selama proses membaca, bila ditemukan kesalahan } \\
\text { langsung diberikan tanggapan }\end{array}$ & 243 & 40 \\
\hline $\begin{array}{l}\text { Setelah satu siswa menyelesaikan bacaan baru diberi } \\
\text { tanggapan }\end{array}$ & 173 & 28.5 \\
\hline $\begin{array}{l}\text { Setelah seluruh siswa menyelasaikan bacaannya baru } \\
\text { diberi tanggapan }\end{array}$ & 191 & 31.5 \\
\hline
\end{tabular}

Cara memberikan umpan balik dari guru kepada siswa ketika pembelajaran membaca adalah yang bersifat langsung ketika siswa membaca secara keras, bila ditemu kesalahan langsung diberikan tanggapan terdapat $40 \%$ siswa memilih kondisi ini, adapun bila seluruh siswa selesai membaca baru diberikan tanggapan sebanyak 31.5\% dan memberi tanggapan setelah satu siswa membaca dipilih sebanyak $28.5 \%$ siswa.

g. Media belajar yang membantu memahami pelajaran bahasa Arab selain buku pelajaran

Tabel 8. Media Belajar

\begin{tabular}{l|c|c}
\hline Media belajar & $\begin{array}{c}\text { Frequency } \\
\text { (N) }\end{array}$ & $\begin{array}{c}\text { Percentage } \\
(\boldsymbol{\%})\end{array}$ \\
\hline Tutorial (petunjuk teknis) & 156 & 25.5 \\
\hline Alat peraga (miniatur dan benda peraga) & 46 & 7.5 \\
\hline Visual (gambar, tabel, poster) & 143 & 23.4 \\
\hline Audio (rekaman mp3, kaset) & 43 & 7 \\
\hline Audio Visual (video, film, animasi) & 224 & 36.6 \\
\hline
\end{tabular}




\section{Arabi : Journal of Arabic Studies}

Berdasarkan tabel 8, media yang membantu siswa dalam memahami pelajaran selain buku teks pelajaran adalah audio visual berupa video film dan animasi yaitu sebanyak 224 siswa (36.6\%), kemudian tutorial teknis sebanyak 156 siswa $(25.5 \%)$, visual berupa gambar, tabel atau poster sebanyak 143 siswa (23.4\%), adapun berupa tutorial sebanyak 46 siswa memilih media tersebut dapat membantu atau sebanyak $7.5 \%$ dan hanya 43 siswa (7\%) yang memilih audio berupa rekaman mp3 atau kaset dapat membatu mereka memahami pelajaran.

h. Cara yang sering gunakan dalam membantu isi pelajaran bahasa Arab yang belum dipahami ketika di luar kelas

Tabel 9. Cara memahami materi di luar kelas

\begin{tabular}{l|c|c}
\hline Cara memahami materi diluar kelas & $\begin{array}{c}\text { Frequency } \\
(\mathbf{N})\end{array}$ & $\begin{array}{c}\text { Percentage } \\
(\mathbf{\%})\end{array}$ \\
\hline Melihat Kamus atau buku) & 150 & 24.5 \\
\hline Mencari sendiri di internet & 150 & 24.5 \\
\hline Bertanya kepada guru & 129 & 21.1 \\
\hline Bertanya kepada teman & 142 & 23.2 \\
\hline $\begin{array}{l}\text { Lainnya (seperti : bertanya kepada orangtua atau } \\
\text { saudara }\end{array}$ & 41 & 6.7 \\
\hline
\end{tabular}

Berdasarkan tabel 9, para siswa lebih suka melihat buku atau kamus dan mencari sendiri sebagai cara memahami isi pelajaran bahasa Arab yang belum dipahami ketika di luar kelas internet sebanyak dengan masing-masing $24.5 \%$, dengan cara bertanya kepada teman sebanyak $23.2 \%$, dan bertanya kepada guru sebanyak $21.1 \%$ sedangkan bertanya kepada orang tua dan saudara hanya $6.7 \%$

i. Tingkat pengunaan teknologi internet dalam memahami pelajaran

Tabel 10. Tingkat penggunaan Internet

\begin{tabular}{l|c|c}
\hline Pengunaan teknologi internet dalam belajar & $\begin{array}{c}\text { Frequency } \\
(\mathbf{N})\end{array}$ & $\begin{array}{c}\text { Percentage } \\
(\mathbf{\%})\end{array}$ \\
\hline Setiap waktu & 75 & 12.3 \\
\hline Sering & 266 & 43.5 \\
\hline Jarang & 263 & 43 \\
\hline Tidak pernah & 8 & 1.3 \\
\hline
\end{tabular}

Tingkat pengunaan teknologi internet untuk memahami pelajaran dikalangan siswa dengan intensitas sering sebanyak $43.5 \%$ atau 266 siswa. dan jarang tetapi mengunakannya sebanyak $43 \%$ atau 263 siswa. pada level setiap waktu adalah $12.3 \%$ dan hanya $1.3 \%$ yang tidak pernah mengunakan teknologi internet untuk memahami pelajaran.

3. Target belajar siswa (Learning Targets)

Pada aspek target belajar ada dua pertanyaan yang digunakan untuk mengetahui target mereka terhadap keterampilan berbahasa dan kegiatan-kegiatan yang mengharuskan mereka berbahasa arab.

a. Aspek keterampilan yang menjadi prioritas pertama untuk dikuasai ketika belajar bahasa Arab

Tabel 11. Keterampilan bahasa yang menjadi prioritas

\begin{tabular}{l|c|c}
\hline Aspek keterampilan prioritas & $\begin{array}{c}\text { Frequency } \\
(\mathbf{N})\end{array}$ & $\begin{array}{c}\text { Percentage } \\
(\mathbf{\%})\end{array}$ \\
\hline Kemampuan membaca teks dan kitab arab & 184 & 30.1 \\
\hline $\begin{array}{l}\text { Kemampuan menulis naskah dan buku bahasa } \\
\text { arab }\end{array}$ & 192 & 31.4 \\
\hline $\begin{array}{l}\text { Kemampuan menyimak dan memahami pidato } \\
\text { dan syair arab }\end{array}$ & 65 & 10.6 \\
\hline $\begin{array}{l}\text { Kemampuan berkomunikasi atau berbicara } \\
\text { bahasa arab }\end{array}$ & 171 & 27.9 \\
\hline
\end{tabular}


Aspek keterampilan yang menjadi prioritas siswa untuk dikuasai berdasarkan tabel 11 adalah kemampuan menulis berbahasa Arab dengan persentasi 31.4\%, kemudian keterampilan membaca teks/kitab berbahasa Arab sebesar 30.1\% sedangkan berkomunikasi dengan bahasa Arab 27.9\% dan terakhir keterampilan menyimak pidato sebanyak $10.6 \%$. keterampilan membaca dan menulis saling berkaitan erat keduanya tidak terpisahkan, Raymond A. Rogers (1972) menyatakan:

"if you would like to improve your writing, do more reading. Of course reading alone will not make you a writer-some writing practice will also be necessary. But reading will bring you to the point where practice can do you some good. Reading is, of course, not the only way to better writing, but it is the easiest, fastest, most convenient, and most generally effective approach you can make. Reading will improve your writing ability more than any other one thing you can do."

(jika Anda ingin memperbaiki tulisan Anda, lakukan lebih banyak kegiatan membaca. Tentu saja membaca saja tidak akan membuat Anda seorang penulis -beberapa latihan menulis juga diperlukan. Tetapi membaca akan membawa Anda kesudut pandang di mana praktik membaca dapat membantu Anda ketika menulis. Membaca tentu saja bukan satu-satunya cara untuk menulis dengan lebih baik, tetapi ini adalah cara termudah, tercepat, paling nyaman, dan paling efektif yang bisa Anda lakukan. Membaca akan meningkatkan kemampuan menulis Anda lebih dari hal lain yang dapat Anda lakukan.)

b. Jenis kegiatan yang sering mengunakan bahasa Arab

Tabel 12. Kegiatan yang sering mengunakan bahasa arab

\begin{tabular}{l|c|c}
\hline $\begin{array}{l}\text { Kegiatan yang sering mengunakan bahasa } \\
\text { arab }\end{array}$ & $\begin{array}{c}\text { Frequency } \\
(\mathbf{N})\end{array}$ & $\begin{array}{c}\text { Percentage } \\
(\mathbf{\%})\end{array}$ \\
\hline Membaca buku, berita,Artikel & 234 & 38.2 \\
\hline Berbicara, pidato dan ngobrol & 148 & 24.2 \\
\hline Mendengar musik, film, perkuliahan & 71 & 11.6 \\
\hline Menulis makalah, sms, email & 13 & 2.1 \\
\hline Tidak ada & 146 & 23.9 \\
\hline
\end{tabular}

Kegiatan kebahasaan yang mengharuskan siswa berbahasa Arab adalah kegiatan membaca buku/kitab, berita dan dan artikel yaitu sebanyak 38,2\%, kemudian kegiatan berbicara, pidato dan ngobrol sebanyak $24.2 \%$, mendengar musik dan belajar sebanyak $11.6 \%$ dan untuk kegiatan menulis sebanyak $2.1 \%$. terdapat $23.9 \%$ siswa memberi respon bawa kegiatan mereka tidak ada yang mengharuskan berbahasa arab

\section{Tahap Perancangan Disain Pembelajaran}

Tahap kedua, yaitu 'perancangan'. Pada tahap ini rancangan pembelajaran yang dibangun mengunakan pengembangan model pembelajaran yang telah dikembangkan oleh Chisanu et al., (2012). Rancangan pembelajaran akan dikembangkan dengan model pembelajaran flipped classroom (Bergmann dan Sams 2012). dengan mengelaborasi 3 ranah ilmu: 1) Ranah psikologis: Beberapa teori pembelajaran yang digunakan adalah teori Konstruktivisme dan teori pengembangan Kognitif yang didasarkan pada pendapat Jean Piaget (1974),(1999), 2) ranah pedagogis: pedagogi yang diacu adalah kerangka kerja dari Constructivist Learning Environment (CLE) Model lingkungan pembelajaran konstruktivistik oleh Jonassen, Peck, \& Wilson (1999) dan Teori sosio kutural dari Vygotsky, (1971), (1978), (1986), 3) ranah teknologi: Teknologi yang digunakan dalam penelitian ini adalah Learning managemen system (LMS). Dari 3 ranah ilmu tersebut dianalisis dan disintesis. Hubungan ketiganya digambarkan dalam gambar 2: 


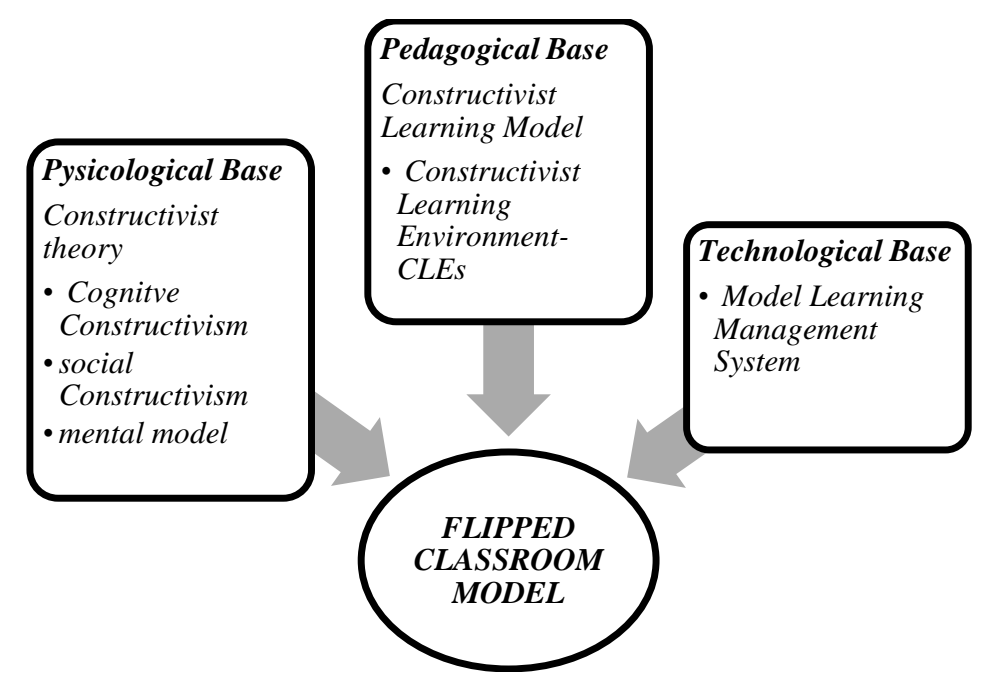

Gambar 2 kerangka teoritik desain pembelajaran Kontruktivistik berbasis Learning Management System

Prinsip dasar yang melandasi filsafat konstruktivisme adalah semua pengetahuan dibangun dan bukan dipersepsi secara langsung oleh indera (penciuman, perabaan, pendengaran, perabaan, dan seterusnya) sebagaimana asumsi kaum realis pada umumnya. Menurut Bruning, Scraw, Norby, \& Ronning sebagaimana dikutip (Supardan, 2016) bahwa tidak ada teori konstruktivisme yang tunggal, tetapi sebagian besar para konstruktivis memiliki setidaknya dua ide utama yang sama; (1) pembelajar aktif dalam mengkonstruksikan pengetahuannya sendiri, dan; (2) interaksi sosial merupakan aspek penting bagi pengkonstruksian pengetahuan

Dalam rancangan pembelajaran yang akan dibangun dalam penelitian ini mengambil pemahaman bahwa belajar harus dilihat lebih hanya sekedar asimilasi pengetahuan baru (mencocokkan informasi baru dengan skema-skema yang sudah ada) pada diri individu, tetapi juga sebagai proses di mana pembelajar harus terintegrasi ke dalam komunitas pengetahuan. Sebagaimana pendapat Eggen \& Kauchak (2013), McInerney \& McInerney (2009) yang memandang konstruksi pengetahuan bukan semata-mata sesuatu yang bersifat individual. Belajar juga dikonstruksikan secara sosial, melalui interaksi dengan teman sebaya, guru, orang tua dan sebagainya. Oleh karena itu pembelajaran sangat tergantung pada kualitas proses kolaboratif dalam komunitas pendidikan, yang merupakan situasi spesifik dan terikat konteks

Dalam konstruktivitik sosial lebih menekankan proses seseorang dalam memaknai dan memahami sesuatu dengan bantuan orang-orang di sekitar individu. Tokoh yang mengembangkan pendekatan ini adalah Vygotsky yang terkenal dengan Zone of Proximal Development (ZPD) dan scaffolding. Konsep Zone of Proximal Development (ZPD) menurut (Vygotsky, 1978) adalah jarak antara tingkat perkembangan aktual yang ditunjukkan oleh kemampuan pemecahan masalah secara mandiri dengan tingkat perkembangan potensial yang ditunjukkan melalui pemecahan masalah dengan bimbingan orang dewasa, atau dengan kolaborasi teman sebaya (peer) yang lebih mampu . Sedang Scaffolding mengacu kepada pemberian sejumlah bantuan oleh teman sebaya atau orang dewasa yang berkompeten kepada siswa, Bantuan yang diberikan dapat berupa petunjuk, peringatan, dorongan, menguraikan masalah dalam bentuk lain yang memungkinkan siswa dapat mandiri.

Adapun Learning Management System (LMS) adalah istilah global untuk sistem komputer yang dikembangkan secara khusus untuk mengelola pembelajaran daring (e-learning) terintegrasi. Ellis, (2010) mendefinisikan LMS sebagai aplikasi perangkat lunak untuk pengadministrasian, dokumentasi, pelacakan, pelaporan dan pengiriman dalam program pembelajaran daring atau program pelatihan. Menurutnya sebuah sistem manajemen pembelajaran yang kuat dapat melakukan hal berikut: 
1) Sentralisasi dan pengotomatisasian administrasi (centralize and automate administration)

2) Penggunaan layanan mandiri dan layanan panduan mandiri (Use self-service and self-guided services)

3) Mengumpulkan dan mengirimkan materi pembelajaran dengan cepat (Assemble and deliver learning content rapidly)

4) Mampu menkonsolidasikan data pembelajaran dengan paltform sistem yang mampu menangani penambahan beban dan perluasan sistem komputer (Consolidate training initiatives on a scalable web-based platform)

5) Dukungan portabilitas dan standar (Support portability and standards)

6) Mendukung personalisasi konten dalam sistem dan memungkinkan materi pelajaran dapat ditinjau berulang-ulang (Personalize content and enable Knowledge reuse).

Banyak peneliti telah mempertimbangkan peran teknologi dalam pendidikan dan menunjukkan bahwa hal itu dapat meningkatkan kualitas pengajaran, memfasilitasi pembelajaran, dan berfungsi sebagai media yang memungkinkan siswa untuk mengekspresikan diri mereka secara lebih penuh dan dengan cara yang kreatif (lihat penelitian: Grant \& Branch, 2005; Papert, 1980). Perangkat berupa fitur diskusi, blog, pengelompokan, tugas, dan rubrik-rubrik soal yang tersedia di LMS selaras dengan prinsip konstruktivisme, karena banyak alat-alat itu bersifat sosial dan mendorong interaksi dengan orang lain dan interpretasi pribadi

Hasil sintesis ketiga teori diatas akan dikembangkan dalam sebuah model pembelajaran yang dikenal dengan Flipped classroom. Flipped classroom pada kenyataannya adalah model pembelajaran yang membalik aktivitas belajar sebagaimana dalam pembelajaran tradisional. Siswa diharuskan untuk mempelajari materi pembelajaran melalui media yang telah disediakan seperti audio visual berupa film atau video tutorial selama mereka di luar kelas dan mereka akan diajak berpartisipasi dalam diskusi di kelas, berlatih, dan menyelesaikan tugas dalam proses belajar di kelas (Zheng, Becker, dan Ding 2014), waktu di dalam kelas akan lebih banyak digunakan untuk interaksi dan pengembangan konseptual, misalnya melalui diskusi antar siswa, memecahkan masalah dan menerapkan pengetahuan konseptual. (DeLozier dan Rhodes 2017).

Telah banyak pendidik melihat efek positif pada pembelajaran siswa di antaranya pengunaan flipped classrom memberi dampak positif pada partisipasi dan keterlibatan siswa (Hamdan et al. 2013), durasi diperoleh siswa waktu yang lebih lama dalam memahami dan mencerna materi (Deslauriers, Schelew, dan Wieman 2011) sehingga lebih siap ketika memasuki ruang kelas dan hasil penelitian Marlowe (2012) membuktikan tingkat stres siswa terhadap pelajaran menjadi lebih rendah ketika mengunaka model flliped classroom.

\section{Simpulan}

Berdasarkan survei yang dilakukan kepada 612 siswa yang tersebar dari 3 MAN (MAN 1, MAN 2 kota Cirebon dan MAN 3 Bunter-Cirebon) dan 5 MAS (MA Madinatun Najah, MAK Salafiyah Kota Cirebon, MA Islamic Centre,MA Darul Masholeh, MA Annur) diperoleh kesimpulan bahwa mayoritas siswa memiliki target penguasaan bahasa, yaitu menulis dan membaca sehingga perlu model pembelajaran yang menitiktekankan pada peningkatan kemampuan ini, setting belajar berkelompok menjadi kegiatan yang mereka lebih sukai ketimbang individu dan berpasangan, selaras dengan target proritas kompetensi yang ingin mereka capai maka setting belajar adalah membaca, melihat gambar, mengamati dengan media belajar berbentuk audio visual, seperti film dan animasi. Tingkat belajar mandiri mereka tinggi terutama berkaitan dengan pengunaan teknologi internet. Hasil dari survei di atas dapat di akses pada laman http://bit.ly/surveisiswaMA

Berdasarkan data tersebut maka rancangan model pembelajaran bahasa arab untuk siswa Madrasah Aliyah di wilayah kota Cirebon dan kabupaten Cirebon mengunakan modell pembelajaran flipped classroom berbasis learning manajemen system atau dikenal dengan elearning. Prinsip pembelajaran menganut prinsip Constructivist Learning Environment. Untuk 


\section{Arabi : Journal of Arabic Studies}

hasil penelitian tahap 'pengembangan' dan 'desiminasi' pada penelitian tahap selanjutnya. Pada dua tahapan terakhir pengembangan yang dimaksud adalah model flipped classroom dalam pembelajaran bahasa Arab berbasis e-learning untuk siswa Madrasah Aliyah di Kota dan Kabupaten Cirebon. Tahapan ini berorientasi produk dan untuk bentuk dasar (prototype) sistem elearning yang akan dikembangkan dapat diakses di laman https://lisan.id/.

Masukan dan saran bagi peneliti adalah perlu upaya pengembangan pembelajaran yang mengombinasikan dua keterampilan bahasa secara bersamaan tanpa dipisah seperti keterampilan membaca dan menulis, keterampilan menyimak dan berbicara. Untuk pemangku kebijakan dalam upaya penyusunan kurikulum perlu upaya pengkajian ulang terkait target kompetensi yang perlu dicapai oleh siswa sehingga terdapat kesinambungan belajar disetiap jenjang pendidikan mulai dari Madrasah Ibtidaiyah/SD hingga tinggat Madrasah Aliyah/SMA.[]

\section{Daftar Rujukan}

Bergmann, Jonathan., \& Aaron Sams. 2012. Flip Your Classroom: Reach Every Student in Every Class Every Day. Washington D.C: International Society for Technology in Education.

Berwick, Richard. 1989. "Needs assessment in language programming: from theory to practice", The Second Language Curriculum, diedit oleh Robert Keith Johnson, Cambridge.

Brindley, Geoffrey. 1989. "The role of needs analysis in adult ESL program design", The second language curriculum, diedit oleh Robert Keith Johnson.

Chisanu, Jiambunsri., Chaijaroen Sumalee., Kanjak Issara., \& Samat Charuni. 2012. "Design and Develop of Constructivist Learning Environment on Learning Management System", Procedia - Social and Behavioral Sciences, Vol. 46.

DeLozier, Sarah J., \& Matthew G. Rhodes. 2017. "Flipped Classrooms: a Review of Key Ideas and Recommendations for Practice”, Educational Psychology Review, Vol. 29, No. 1.

Deslauriers, Louis., Ellen Schelew., dan Carl Wieman. 2011. "Improved learning in a largeenrollment physics class", Science, Vol. 332.

Eggen, Paul., \& Don Kauchak. 2013. Educational Psychology: Windows on Classrooms. 9th ed. London: Pearson.

Ellis, Ryann K. 2010. “A Field Guide to Learning management systems”, ASTD Learning Circuits, Vol. 48, No. 3.

Grant, Michael M., \& Robert Maribe Branch. 2005. "Project-Based Learning In a Middle School", Journal of Research on Technology in Education, Vol. 38, No. 1.

Graves, Kathlen. 2000. Designing language course: A guide for teachers. Boston: Heinle \& Heinle publishers.

Hamdan, Noora., Patrick McKnight., Katherine McKnight., \& Kari M. Arfstrom. 2013. “A Review of Flipped Learning", Flipped Learning Network.

Hayland, Ken. 2006. English for academic purposes: an advanced resource book. New York: Routledge.

Hizbullah, Nur., \& Zaqiatul Mardiah. 2014. "Masalah Pengajaran Bahasa Arab di Madrasah Aliyah di Jakarta", Al-Azhar Indonesia Seri Humaniora, Vol. 2, No. 3.

Hutchinson, Tom., \& Alan Waters. 1987. English for specific purposes: A learning-centred approach. Cambridge: Cambridge University Press.

Jiajing, Gao. 2007. "Designing an ESP course for Chinese University Students of Business", The Asian ESP Journal, Vol. 3, No. 1. 
Jonassen, David H., Kyle L. Peck., \& Brent G. Wilson. 1999. Learning with technology: a constructivist perspective. Upper Saddle River, NJ: Merrill/Prentice Hall.

Marlowe, Cara A. 2012. "The Effect of the Flipped Classroom on Student Achievement and Stress", Thesis, Montana State University.

McInerney, Dennis Michael., \& Valentina McInerney. 2009. Educational psychology: constructing learning. 6th ed. Melbourne: Pearson Education Australia.

Munby, J. 1978. Communicative Syllabus Design. Cambridge: Cambridge University Press.

Papert, Seymour. 1980. Mindstorms: Children, Computers, and Powerful Ideas. New York: Basic Books.

Piaget, Jean. 1974. To understand is to invent: The future of education. New York: Grossman.

Piaget, Jean. 1999. Judgment and reasoning in the child. London: Routledge. Taylor and Francis group.

Richards, Jack C. 2001. Curriculum development in language teaching. Cambridge: Cambridge University Press.

Richterich, Rene., \& Jean-Louis Chancerel. 1980. Identifying the needs of adults learning foreign language. Oxford: Pergamon Press for the Council of Europe.

Rogers, Raymond A. 1972. "The Relationship Between Reading And Writing”, The Journal of Technical Writing and Communication, Vol. 2, No. 2.

Sadeghi, Bahador., Mohammad Taghi Hassani., \& Ahmad Dashtaki Hessari. 2014. "On the Relationship between Learners' Needs and their Use of Language Learning Strategies", Procedia - Social and Behavioral Sciences, Vol. 136.

Saifulloh, Hasan. 2015. "Kegagalan Pembelajaran Bahasa Arab di Madrasah: Faktor-faktor Penyebab dan Alternatif Solusinya", El-Ibtikar, Vol. 4, No. 1.

Supardan, Dadang. 2016. "Teori Dan Praktik Pendekatan Konstruktivisme dalam Pembelajaran”, Edunomic, Vol. 4, No. 1.

Thiagarajan, Sivasailam., Dorothy Semmel., \& Melvyn I Semmel. 1974. Instructional Development for Training Teachers of Exceptional Children: A sourcebook. Indiana: Indiana University.

Vygotsky, Lev Semenovich. 1971. Psychology of Art. Diterjemahkan oleh Inc Scripta Technica. Cambridge, MA: MIT Press.

Vygotsky, Lev Semenovich. 1986. Thought and Language. Disunting \& diterjemahkan oleh Alex Kozulin. Cambridge,MA: MIT Press.

Vygotsky, Lev Semyonovich. 1978. Mind in Society: The Development of Higher Psychological Processes. Diedit oleh Michael Cole, Vera John-Steiner, Sylvia Scribner, dan Ellen Souberman. Cambridge, MA: Harvard University Press.

West, Richard. 1997. "Needs Analysis: State of the Art." In Teacher Education for LSP, diedit oleh Ron Howard dan Gillian Brown. Clevedon, UK: Multilingual Matters Ltd.

White, Ronald. 1988. The ELT Curriculum. Diedit oleh Crystal Johnson. Oxford: WileyBlackwell.

Zheng, Wei., Timothy Becker., dan Xuedong Ding. 2014. "The Effects of" Flipped Classroom" Concept on the Effectiveness of Teaching," Proceedings, ASEE North Midwest Section Conference. 